\title{
Operational performance of tractor running with diesel and biodiesel from buriti oil (Mauritia flexuosa)
}

\author{
Priscila Sawasaki Iamaguti ${ }^{1}$, Afonso Lopes ${ }^{1}$, Melina Cais Jejcic de Oliveira ${ }^{1}$, Murilo Coelho \\ Theodoro Neves ${ }^{1}$, Thyago Augusto Medeiro Lira ${ }^{1}$, Thaisa Calvo Fugineri Moreti ${ }^{1}$, Leomar Paulo de \\ Lima $^{2}$, Gilberto Hirotsugu Azevedo Koike ${ }^{3}$
}

${ }^{1}$ Universidade Estadual Paulista - UNESP, Campus Jaboticabal/SP, Access Road Prof. Paulo Donato Castellane, Zip Code: 14884-900 Jaboticabal/SP - Brazil

${ }^{2}$ Instituto Federal do Triângulo Mineiro- IFTMG, Campus Uberlândia/MG, Fazenda Sobradinho, Zip code: 38400-970 Uberlândia/MG - Brazil - Post Office Box: 592

${ }^{3}$ Autonomous Consultant - Ribeirão Preto/SP - Brazil

\section{*Corresponding author: priiamaguti@ hotmail.com; priiamaguti@gmail.com}

\begin{abstract}
Biodiesel is made from vegetable oils, animal fats or residual oil by reaction with ethanol or methanol, renewable fuel sources decrease environmental problems. The purpose of this study is to evaluate the operational performance and smoke density of an agricultural tractor running ethyl biodiesel from buriti oil (Mauritia flexuosa), diesel B S50 and diesel B S1800. Each type of diesel was mixed with biodiesel according proportions B0, B5, B15, B25, B50 and B75, in which the number indicates the percentage of biodiesel in diesel. Fuel consumption (volumetric, weight, and specific), drawbar force and power, real travel speed and smoke density were evaluated. Replacing B S1800 and B S50 (B0 diesels) with B100 reduced smoke density by $33.33 \%$ and $28.90 \%$, respectively. The results showed an increase of $5.41 \%$ in specific fuel consumption comparing B0 and B100. Finally, biodiesel can be considered totally or as blending for fueling tractors.
\end{abstract}

Keywords: fuel; specific consumption; tractor test; density of smoke; tillage.

Abbreviations: SFC_specific fuel consumption $\left(\mathrm{g} \mathrm{kW} \mathrm{h}^{-1}\right)$; WHC $(\mathrm{kW})$; Sv_supply fuel volume $(\mathrm{mL})$; Dsf_fuel supply density $\left(\mathrm{kg} \mathrm{m}^{-3}\right) ; \mathrm{Rv}_{-}$return fuel volume $(\mathrm{mL})$; Drf_return fuel density $\left(\mathrm{kg} \mathrm{m}^{-3}\right)$; t_travel time (s); HVC_hourly volumetric fuel consumption $\left(\mathrm{L} \mathrm{h}^{-1}\right)$; BIOEM_biofuel and machinery test; B0_0\% of biodiesel; B5_5\% of biodiesel; B10_10\% of biodiesel; B15_15\% of biodiesel; B20_20\% of biodiesel; B25_25\% of biodiesel; B50_50\% of biodiesel; B75_75\% of biodiesel; B100_100\% of biodiesel; CPB10_10\% of Ceiba petandra biodiesel; CPB20_20\% of Ceiba petandra biodiesel; CPB30_30\% of Ceiba petandra biodiesel; CPB40_40\% of Ceiba petandra biodiesel; UNESP_Universidade Estadual Paulista; LADETEL_ development of clean technologies; USP_ University of Sao Paulo; CAPES_ higher level personnel improvement Brazilian commission ANP_Brazilian national agency of petroleum.

\section{Introduction}

Diesel oil is a fuel with complex composition which consists essentially of paraffinic, olefin and aromatic hydrocarbons, and also contains impurities such as sulfur, nitrogen and metals These hydrocarbons are constituted of molecules from 8 to 40 carbon atoms, usually being heavier than those comprising gasoline (Souza, 2005; Demirbas, 2009). Diesel oil consumption has been the subject of governmental discussions mainly related to environmental issues motivated by the increase in demand. According to the National Energy Balance, (BRASIL, 2013) presented by the Ministry of Mines and Energy, diesel oil fuels approximately $48.1 \%$ of the transportation of goods and people in Brazil, which is the main energy matrix of the Brazilian domestic market. The world consumption of diesel oil in 2013 was 91.3 million barrels per day (BP Statistical Review of World Energy, 2014). Recently, the use of biofuels has been supported by government policies searching for low-carbon fuel for the near future and better energy security through the partial substitution of fossil fuels (Kalam et al., 2011).

Studies on renewable liquid fuel production demonstrate that large-scale production can replace petroleum derived fuels (Brown and Brown, 2013; Mccurdy et al., 2014). Biodiesel is one of the most promising renewable fuel, and has been produced from various raw feedstocks such as oil from crops and residual oils (Vasudevan and Briggs, 2008). The potential of biofuels as an environment friendly source arose after successive crises of the world's oil reserves (Lima et al, 2013). Besides being an important alternative to develop diverse sources of clean energy, it is renewable and completely miscible with conventional petroleum diesel (Ramirez et al., 2014), therefore it is usually tested as blend (Graboski and Mccormick, 1998). Due to possible shortages of fossil fuel buriti palm (Mauritia flexuosa) readily available in the Amazon region, fits as a promising alternative to increase biodiesel production (Durães et al., 2006). The study 
of these oils as source to obtain biodiesel is important since native vegetable oils from Brazilian regions are not normally used for human consumption (Luz Jr. et al., 2010). Several studies have been conducted in order to improve the synthesis and consuption of biodiesel. The goal of this study is to compare diesel B S1800 and diesel B S50 with different blend proportions of buriti oil derived ethyl biodiesel, and evaluate performance and engine smoke density of each during soil tillage using agricultural tractors.

\section{Results and Discussion}

The results of each variable were discussed in separate topics to facilitate comprehension and are presented in the form of Tables, Figures and Equations. The summary of the statistical analysis was presented as groups of variables in Tables 1 and 2 . In these tables, data relating to factors such as, type of diesel and blend proportion is represented as means of 14 and 6 observations, respectively.

\section{Test I - Agricultural tractor performance}

\section{Average from drawbar power}

From the experimental data in Table 1, it can be seen that the type of diesel and proportion of ethyl biodiesel from buriti oil did not influence the variable average in drawbar power. Silitonga et al. (2013) study the engine performance at different engine speeds using proportions of 10, 20, 30 and $50 \%$ of biodiesel in diesel concluded that B10 blend showed the best result in engine power at $1900 \mathrm{rpm}$ under full acceleration conditions.

\section{Tractor forward speed}

Type of diesel and its proportions with ethyl biodiesel from buriti oil did not influence on tractor forward speed (Table 1). Evaluating performance of tractor running with biodiesel from babassu (Attalea ssp.) and tucuma (Astrocaryum aculeatum) as fuel, obtained similar results (Lima et al., 2012).

\section{Fuel consumption}

Table 2 illustrates the synthesis of variance analysis and mean testing: volumetric hourly consumption, hourly weight consumption and specific fuel consumption.

\section{Volumetric hourly fuel consumption}

As shown in Table 2, the type of diesel did not affect volumetric hourly fuel consumption. Testing Valtra tractor, model BM110, running with diesel oil B S1800, diesel B S500 and biodiesel from castor oil, lower fuel consumption was observed for B S500 diesel claiming to have better quality than the B S1800 diesel fuel (Tabile et al., 2009).

\section{Weight hourly fuel consumption}

As shown in Table 2, it can be seen that the type of diesel did not influence fuel weight consumption. Contradictorily, testing with diesel B S500, fuel consumption was 3.7\% lower when compared with diesel B S1800. According the authors, the contradiction is likely due to the lower density of B S1800 fuel, since these characteristics influence the fuel weight consumption calculation (Tabile et al., 2009).

The results in Table 2 show a significant difference in biodiesel proportion analysis. It is noted that fuel weight consumption was similar between the proportions B0, B5, $\mathrm{B} 15, \mathrm{~B} 25$ and B50. It was also noted that B15 was similar to
B25, B50, B75 and the other proportions were different. Comparing B0 with B100 the results show an increase of $10.8 \%$ in fuel weight hourly fuel consumption. The difference between proportions was corrected because of the effect of biodiesel density. There is an ideal relationship between air and fuel mass when the engine is running, so volumetric fuel consumption can be converted into weight fuel consumption (Neves et al., 2013).

\section{Specific fuel consumption}

In Table 2, it was concluded that there was no significant difference for specific fuel consumption according to the type of diesel. Results were verified regarding blend proportions from addition of $15 \%$ of ethyl biodiesel from buriti oil, there was a significant difference in the specific fuel consumption compared to diesel. However, contrasting B0 and B100, it could be seen that consumption increased by $14.8 \%$. In agreement with these results, experiments that were carried out in a diesel power generator fueled with blends of castor oil or soybean biodiesel and diesel oil showed that specific fuel consumption increases with increased biodiesel content (Valente et al., 2010). Experimental tests were conducted with the addition of $10,20,30$ and $50 \%$ biodiesel, it was concluded that B10 showed specific fuel consumption approximately $22.98 \%$ than diesel (Silitonga et al., 2013). The behavior of specific fuel consumption depending on blend proportion was adjusted to fit a linear regression model, shown in Figure 1.

\section{Test II - Tractor smoke opacity}

Table 3 shows the average smoke density data regarding the factors, type of diesel and proportions of ethyl biodiesel from buriti oil. The results represent means of 14 and 6 observations, respectively. Smoke density is related to the total particles; the darker smoke is, the greater the density is. Smoke density is also used as an indicator of problems in fuel combustion during inspections and maintenance programs (Graboski and Mccormick, 1998). It was observed that the type of diesel and biodiesel proportional blend significantly affected the smoke density, this interaction was further analyzed using an additional deployment table (Table 4).

In Table 4, analyzing type of diesel (in line), the smoke density reduced $33.33 \%$ and $28.9 \%$ comparing B0 and B100, and B S1800 and B S50, respectively. This result could be explained by the low rates of particulate matter emissions in biodiesel and its blends when compared with diesel oil. This characteristic lower particle emission is caused by the high free oxygen content in biodiesel, which increases the amount of oxygen present in the combustion chamber, therefore reducing the amount of soot formed (Graboski and Mccormick, 1998). Increasing proportions of biodiesel from soy and murumuru palm in an agricultural tractor equipped with intercooler turbo charger was reduced by $26.1 \%$ and $53.5 \%$, respectively (Neves et al., 2013). By adjusting the proportion of biodiesel from Ceiba pentandra with diesel, it was noted that densities were lower in all speeds that were tested , CPB10 reduced by $20.58 \%$, proving that higher thermal efficiency results on better fuel combustion. For CPB20, CPB30 and CPB50 blends, smoke density decreased as biodiesel proportion increased: $17.11 \%, 12.70 \%$ and $9.35 \%$, respectively. These results can be explained by the low fuel volatility in the combustion chamber, which generates slow combustion (Silitonga et al., 2013). Biodiesel from Pongamia oil and its blends showed that there was a reduction in smoke density when compared to diesel. It can also be concluded that biodiesel from Pongamia oil and its 
Table 1. Summary of variance analysis and mean test for the variables, force on the drawbar, average power on the drawbar and tractor foward speed.

\begin{tabular}{lcc}
\hline Factors & $\begin{array}{c}\text { Power } \\
\mathrm{kW}\end{array}$ & $\begin{array}{c}\text { Speed } \\
\mathrm{km} \mathrm{h}^{-1}\end{array}$ \\
\hline Type of Diesel (TD) & $44.41 \mathrm{a}$ & $6.53 \mathrm{a}$ \\
B S1800 & $44.75 \mathrm{a}$ & $6.40 \mathrm{a}$ \\
B S50 & & \\
\hline Biodiesel Proportion (Bp) & $45.81 \mathrm{a}$ & $6.88 \mathrm{a}$ \\
B0 & $45.12 \mathrm{a}$ & $6.35 \mathrm{a}$ \\
B5 & $44.25 \mathrm{a}$ & $6.43 \mathrm{a}$ \\
B15 & $43.86 \mathrm{a}$ & $6.41 \mathrm{a}$ \\
B25 & $44.79 \mathrm{a}$ & $6.42 \mathrm{a}$ \\
B50 & $44.09 \mathrm{a}$ & $6.41 \mathrm{a}$ \\
B75 & $44.13 \mathrm{a}$ & $6.38 \mathrm{a}$ \\
B100 & & \\
\hline F TEST & $0.7410 \mathrm{NS}$ & $0.7711 \mathrm{NS}$ \\
TD & $1.8453 \mathrm{NS}$ & $0.9015 \mathrm{NS}$ \\
Bp & $2.1014 \mathrm{NS}$ & $1.0286 \mathrm{NS}$ \\
TDxBp & 2.82 & 7.32 \\
\hline C.V.(\%) & 44.58 & 6.47 \\
\hline Mean & & $\mathrm{a} 5 \%$ \\
\hline
\end{tabular}

Means followed by the same lower case letter in the column do not differ by Tukey's test at $5 \%$ of probability **significant (P $\leq 0.01)$; *significant (P $\leq 0.05)$; NS: not significant; C.V.: coefficient of variation.

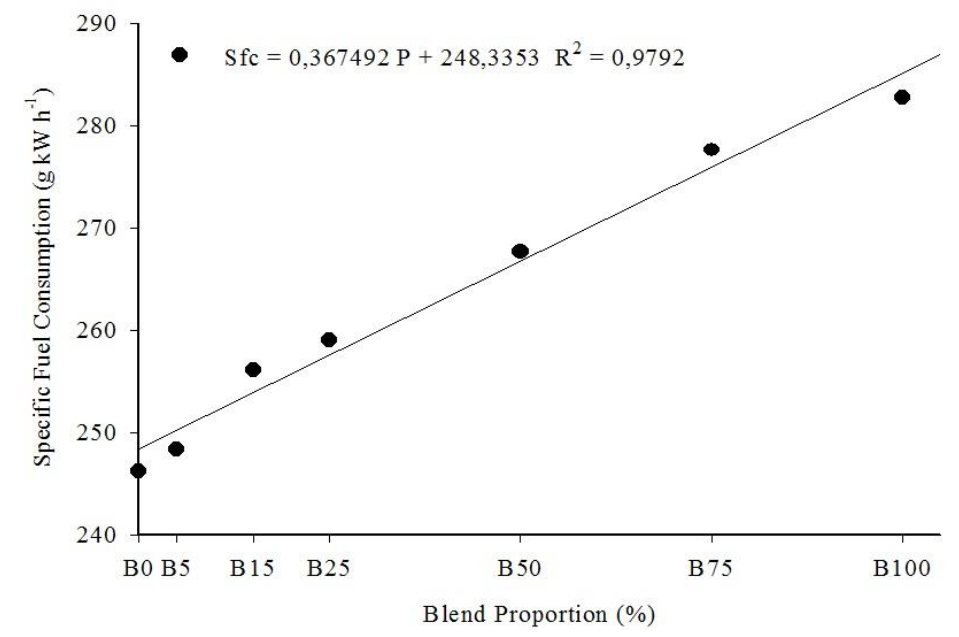

Fig 1. Linear regression model for specific fuel consumption according to the proportion of ethyl biodiesel from buriti oil.

blends can be used in conventional diesel engines without any modification (Chauhan et al., 2013). The use of biodiesel from Pequi oil has the potential to replace diesel due to its' high thermally stable (Silva et al., 2014). Table 4, analyzes biodiesel proportion (column), it was confirmed that diesel B S50 had better results compared to diesel B S1800. Smoke density reduction is favorable to use of biodiesel, which was partially explained by the default of sulfur. Sulfur competes with available oxygen in the last phase of combustion of carbon resulting in partial burning, increasing the amount of particulate matter in some engine operational conditions (Mazziero et al., 2006).

After monitoring smoke density, and analyzing the data, linear models were made for diesel B S1800 and B S50, as shown in Figure 2.

\section{Materials and Methods}

\section{Experimental area}

The experiment was carried out on May 20, 2013, in the Biocombustivel e Ensaio de Maquinas - BIOEM of the Rural Engineering Department, in the State University of São Paulo
- UNESP - Jaboticabal - SP, Brazil. The area is located lateral to the Access Road Prof. Paulo Donato Castellane, $\mathrm{km}$ 5 , geodesic coordinates $21^{\circ} 15^{\prime}$ south and $48^{\circ} 18^{\prime}$ east, 570 meters above the sea level. The annual average temperature is $22,2{ }^{\circ} \mathrm{C}$, annual average precipitation is $1.425 \mathrm{~mm}$, average relative humidity of $71 \%$ and an atmospheric pressure of 94,3 $\mathrm{kPa}$ (UNESP, 2013). The regional weather is classified by Köeppen as Cwa, defined as subtropical with dry winter in transition to Aw, tropical-wet with defined rain period in summer and drought winter. The soil of the area was classified as Eutrustox, with gently rolling topography and average slope of 3\% (Andreoli and Centurion, 1999). The average water content by gravimetric method on the experiment day was 11,2 and $13,4 \%$ for $0-15$ and $15-30 \mathrm{~cm}$ deep, respectively. The soil particle size at $0-20 \mathrm{~cm}$ layer to clay, silt, fine and coarse sand was 51, 29, 10 and 10\%, respectively, being classified as clayey.

\section{Fuel and biodiesel}

The biodiesel used was ethyl biodiesel from buriti oil (Mauritia flexuosa). The production process and the supply of biofuel provided by the Laboratory for the Development of 
Table 2. Average results for the variables hourly volumetric fuel consumption (HVC), weight hourly fuel consumption (WHC) and specific fuel consumption (SFC).

\begin{tabular}{|c|c|c|c|}
\hline Factors & $\begin{array}{l}\mathrm{HVC} \\
\mathrm{L} \mathrm{h}^{-1}\end{array}$ & $\begin{array}{l}\text { WHC } \\
\mathrm{kg} \mathrm{h}^{-1}\end{array}$ & $\begin{array}{c}\text { SFC } \\
\mathrm{g} \mathrm{kW} \mathrm{h}^{-1}\end{array}$ \\
\hline \multicolumn{4}{|c|}{ Type of Diesel (TD) } \\
\hline B S 1800 & $13.63 \mathrm{a}$ & $11.57 \mathrm{a}$ & $260.69 \mathrm{a}$ \\
\hline B S50 & $13.76 \mathrm{a}$ & $11.80 \mathrm{a}$ & $264.32 \mathrm{a}$ \\
\hline \multicolumn{4}{|c|}{ Biodiesel Proportion (Bp) } \\
\hline B0 & $13.46 \mathrm{a}$ & $11.26 \mathrm{a}$ & $246.19 \mathrm{a}$ \\
\hline B5 & $13.28 \mathrm{a}$ & $11.18 \mathrm{a}$ & $248.31 \mathrm{ab}$ \\
\hline B15 & $13.39 \mathrm{a}$ & $11.33 \mathrm{ab}$ & $256.08 \mathrm{ab}$ \\
\hline B25 & $13.35 \mathrm{a}$ & $11.35 \mathrm{ab}$ & $258.99 \mathrm{abc}$ \\
\hline B50 & $14.08 \mathrm{a}$ & $11.98 \mathrm{abc}$ & $267.66 \mathrm{bcd}$ \\
\hline B75 & $14.09 \mathrm{a}$ & $12.23 \mathrm{bc}$ & $277.59 \mathrm{~cd}$ \\
\hline B100 & $14.23 \mathrm{a}$ & $12.48 \mathrm{c}$ & $282.72 \mathrm{~d}$ \\
\hline \multicolumn{4}{|l|}{ F TEST } \\
\hline TD & $0.5599^{\mathrm{NS}}$ & $2.1743^{\mathrm{NS}}$ & $1.1609^{\mathrm{NS}}$ \\
\hline $\mathrm{B}_{\mathrm{p}}$ & $3.0582^{\mathrm{NS}}$ & $6.5773 * *$ & $9.8912 * *$ \\
\hline $\mathrm{TDxB}_{\mathrm{p}}$ & $1.6859^{\mathrm{NS}}$ & $1.6457^{\mathrm{NS}}$ & 0.6361 NS \\
\hline C.V.(\%) & 4.24 & 4.32 & 4.16 \\
\hline Mean & 13.70 & 11.69 & 262.51 \\
\hline
\end{tabular}

Means followed by the same lower case letter in the column do not differ by Tukey's test at $5 \%$ of probability $* *$ significant $(\mathrm{P} \leq 0.01)$; ${ }^{*}$ significant $(\mathrm{P} \leq 0.05)$; ${ }^{\text {ss }}$ : not significant; C.V.: coefficient of variation.

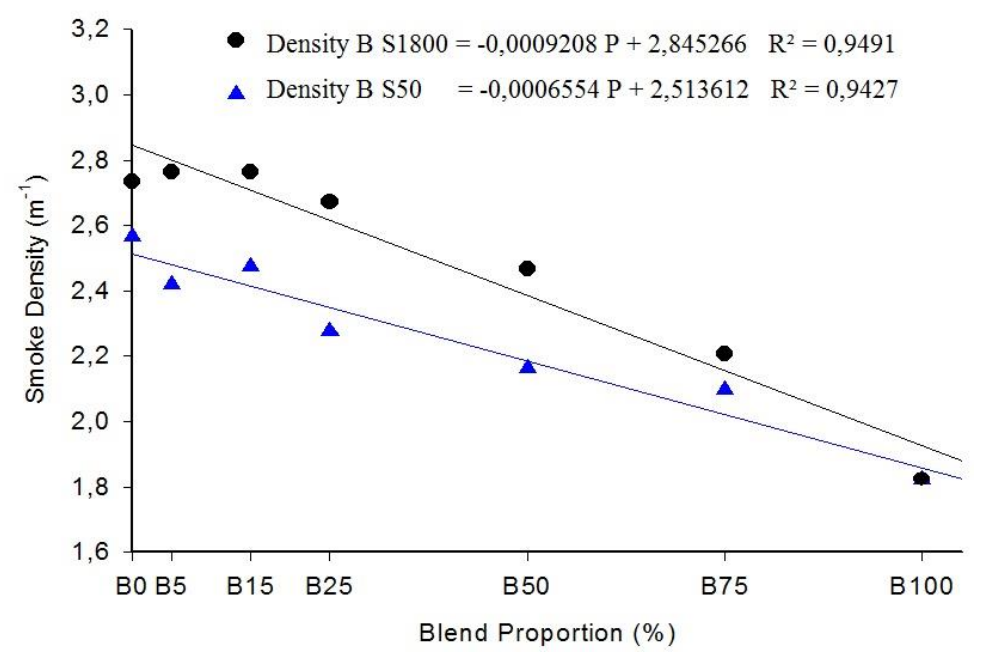

Fig 2. Regression model for the smoke density depending on the type of diesel (B S1800 and B S50) and the proportions of blends of ethyl biodiesel from buriti oil with diesel.

Table 3. Summary of variance analysis and mean test for smoke density.

\begin{tabular}{lc}
\hline Factors & $\begin{array}{c}\text { Smoke Density } \\
\left(\mathrm{m}^{-1}\right)\end{array}$ \\
\hline Type of Diesel (TD) & 2.49 \\
B S1800 & 2.26 \\
B S50 & \\
\hline Biodiesel Proportion (Bp) & 2.65 \\
B0 & 2.59 \\
B5 & 2.61 \\
B15 & 2.47 \\
B25 & 2.31 \\
B50 & 2.15 \\
B75 & 1.82 \\
B100 & \\
\hline F TEST & $527.0095 * *$ \\
TD & $524.3373 * *$ \\
$B_{\mathrm{p}}$ & $28.4971 * *$ \\
TBxB & 2.72 \\
\hline C.V.(\%) & 2 \\
\hline wed by the same lower case letter in the column do not differ by Tukey's test at 5\% of probability ** significant $(\mathrm{P} \leq 0.01) ;{ }^{*}$ significant (P $\left.\leq 0.05\right) ;$ NS: not
\end{tabular}
Means followed by the same lower case letter in the column do not differ by Tukey's test at $5 \%$ of probability **significant (P $\leq 0.01)$; *significant (P $\leq 0.05)$; NS: not
significant; C.V.: coefficient of variation. 
Table 4. Summary of deployment interaction type of diesel and proportion of ethyl biodiesel from buriti oil for smoke density $\left(\mathrm{m}^{-1}\right)$.

\begin{tabular}{lccccccc}
\hline & \multicolumn{7}{c}{ Biodiesel Proportion } \\
\cline { 2 - 7 } Type of diesel & $\mathrm{B} 0$ & $\mathrm{~B} 5$ & $\mathrm{~B} 15$ & $\mathrm{~B} 25$ & $\mathrm{~B} 50$ & $\mathrm{~B} 75$ & $\mathrm{~B} 100$ \\
\hline B S1800 & $2.73 \mathrm{Aab}$ & $2.76 \mathrm{Aa}$ & $2.76 \mathrm{Aa}$ & $2.67 \mathrm{Ab}$ & $2.46 \mathrm{Ac}$ & $2.20 \mathrm{Ad}$ & $1.82 \mathrm{Ae}$ \\
B S50 & $2.56 \mathrm{Ba}$ & $2.2 \mathrm{Bb}$ & $2.47 \mathrm{Bb}$ & $2.27 \mathrm{Bc}$ & $2.16 \mathrm{Bd}$ & $2.09 \mathrm{Bd}$ & $1.82 \mathrm{Ae}$ \\
\hline Means followed by the same capital letter in the column and lower case in line do not defer from each other by Tukey's test at 5\% of probability.
\end{tabular}

Clean Technologies (LADETEL) at University of Sao Paulo USP, Campus Ribeirao Preto - SP, Brazil. Diesel B S1800 and diesel B S50 used in this experiment were classified in accordance with the resolution of the ANP (Brazilian national agency of petroleum) No. 65, December 9, 2011 (ANP, 2013), acquired in the city of Jaboticabal/SP. The blending of biodiesel was performed before each test and all biodiesel that was not consumed was collected from deposits. Filters and piping were drained to avoid the contamination of subsequent testing. For the stabilization of the experiment, after changing the fuel, the engine remained in operation for ten minutes before the beginning of each test.

\section{Tractors}

A BM 125i model Valtra tractor was used in each test, $4 \times 2$ front wheel assist (FWA), power of $91.9 \mathrm{~kW}$ (125 hp) at 2300 rpm (ISO1585), equipped with turbocharger and intercooler, total mass of $7000 \mathrm{~kg}$ distributed in $40 \%$ and $60 \%$ on the front and rear axles, respectively, mass/power relation of 76 $\mathrm{kg} / \mathrm{kW}(56 \mathrm{~kg} / \mathrm{hp}$ ), equipped with 14.9-24 tires on the front axle and 23.1-30 tires on the rear axle which were inflated according to the manufacturer's recommendation. At the moment of the experiment, the working speed was $2100 \mathrm{rpm}$. A second Valtra tractor, model $118-4$, 4x2 front wheel assist (FWA), power of $82.43 \mathrm{~kW}(112 \mathrm{hp})$ at $24000 \mathrm{rpm}$, total mass of $7310 \mathrm{~kg}$ distributed in $40 \%$ and $60 \%$ on the front and rear axles, respectively, equipped with 14.9-28 tires on the front axle and 23.1-30 tires on the rear axle. This tractor, which had the function to provide load on the traction bar to simulate the work with chisel plow, was coupled to the first tractor by means of a steel cable. It was turned off and geared, since the only function was to provide the most possible uniform load on the tractor drawbar, with operating speed achieved with the combination of the 4 th gear, range $\mathrm{L}$.

\section{Instrumentation}

The test tractor was equipped with a load cell, radar unit, data acquisition system (model CR23X) and a consumption meter prototype containing three auxiliary tanks for biodiesel (Lopes, 2006).

\section{Experiment conduction}

The experiment was divided into two stages. The first one was conducted under field conditions to evaluate the tractor performance by measuring volumetric, weight and specific fuel consumption. The second tractor, which provided load on the traction bar in order to simulate the work with chisel plow, was coupled to the first tractor by means of a steel cable. Previously, preliminary tests were conducted with the first tractor using a chisel plow (pilot experiment) in order to set the load corresponding to maximum effort technically feasible, that the first tractor could pull. It is noteworthy that the load was achieved through a combination of the gears of the second tractor with $23 \mathrm{kN}$. The load was obtained by combining gears of second tractor, wherein the resultant force was $25 \mathrm{kN}$. In all plots, aiming to stabilize the measurements, the tractor started movement $15 \mathrm{~m}$ before the first landmark, which marked the beginning of measurement. When the referential of tractor, the center of rear wheel coincided with the first landmark, the data acquisition system was activated. The procedure was stopped at $40 \mathrm{~m}$ when the center of rear wheel coincided with the second landmark.

\section{Fuel consumption}

The fuel consumption was measured by the difference of volume and temperature among the fuel supplied to the injection pump and fuel returned to the tank. With this data, hourly consumption (volumetric and gravimetric) and specific consumption were determined.

Based on the volume consumed and the trajectory time from each plot, hourly volumetric consumption was determined according to equation (1):

$H V C=\left(\frac{S v-R v}{t}\right) * 3.6$

where,

$\mathrm{HVC}=$ hourly volumetric consumption $\left(\mathrm{L} \mathrm{h}^{-1}\right)$;

$\mathrm{Sv}=$ supply fuel volume $(\mathrm{mL})$;

$\mathrm{Rv}=$ return fuel volume $(\mathrm{mL})$;

$\mathrm{t}=$ travel time (s), and

$3.6=$ conversion factor.

To calculate weight hourly fuel consumption the fuel density was considered, by influence of supplied and returned fuel during the test, according to equation (2):

$W H C=\left(\frac{S v * D s f-R v * D r f}{t}\right) * 0.0036$

(2)

where,

WHC = weight hourly fuel consumption $\left(\mathrm{kg} \mathrm{h}^{-1}\right)$;

$\mathrm{Sv}=$ supply fuel volume $(\mathrm{mL})$;

Dsf = fuel supply density $\left(\mathrm{kg} \mathrm{m}^{-3}\right)$;

$\mathrm{Rv}=$ return fuel volume $(\mathrm{mL})$;

Drf = return fuel density $\left(\mathrm{kg} \mathrm{m}^{-3}\right)$;

$\mathrm{t}=$ travel time $(\mathrm{s})$, and

$0,0036=$ conversion factor.

Specific fuel consumption is the consumption of fuel expressed in units of mass per unit of power required in the drawbar, according to equation (3):

$S F C=\left(\frac{W H C}{D p}\right) * 1000$

(3)

where,

$\mathrm{SFC}=$ specific fuel consumption $\left(\mathrm{g} \mathrm{kW} \mathrm{h}^{-1}\right)$;

WHC = weight hourly fuel consumption $\left(\mathrm{kg} \mathrm{h}^{-1}\right)$;

$\mathrm{Dp}=$ Drawbar power $(\mathrm{kW})$, and

$1000=$ conversion factor.

\section{Opacity}

The second stage was conducted in accordance with the snapacceleration smoke test, in which the throttle is moved to its maximum and remains in this position until the engine reaches the maximum governed speed, and held for an additional 1 to 4 seconds, with the developed power absorbed only by the inertia of the mechanical engine components (clutch, primary tree of the gearbox), according to NBR 13037 (ABNT, 2001). Smoke density (K), is the coefficient of light absorption having unit $\mathrm{m}^{-1}$ (SAE, 1996). The smoke 
density was measured by a partial-flow opacimeter TM 133 , attached to a serial TM 616, both produced by Tecnomotor, which transmitted the data to a computer with specific software called IGOR, version 2.0. Both tests were performed with a randomized $6 \times 2$ factorial design with 3 repetitions, totaling 36 observations. The combinations of factors were 7 proportions of biodiesel/diesel blend (B0, B5, B25, B50, B75 and B100 in which the letter indicates the presence of biodiesel and the number indicates the percentage of biodiesel in diesel) and two types of diesel (BS 1800 and BS 50). For the performance test, each plot had $40 \mathrm{~m}$ in length in the longitudinal direction, an area of $15 \mathrm{~m}$ was reserved for maneuvers, machinery traffic and stabilization of machines in each treatment.

\section{Data analysis}

Data were studied and submitted to variance analysis and Tukey's range test at 5\% probability. In this study, variance analysis was used (F-test) to select the equation model with the most significant exponent. For specific fuel consumption and smoke density, the regression adjustment model that was more appropriate to explain the behavior of these variables according to the proportion of biodiesel was studied.

\section{Conclusions}

Diesel B S1800, diesel B S50, ethyl biodiesel from buriti oil and it blends proportions did not influence the performance of agricultural tractor. Specific fuel consumption increased by $5.41 \%$ comparing $\mathrm{B} 0$ and $\mathrm{B} 100$. In this variable, there was no difference for the 2 types of diesel. Comparing B0 and B100, smoke density reduced $33.33 \%$ and $28.90 \%$ working with diesel B S1800 and B S50, respectively. The smoke density of B S50 was $6.22 \%$ lower than B S1800.

\section{Acknowledgements}

The author would like to thank CAPES (Coordenação de Aperfeiçoamento de Pessoal de Nível Superior) for their valuable support.

\section{References}

ABNT - Brazilian association of technical standards (2001) NBR 13037: Veículos rodoviários automotores gás de escapamento emitido por motor em aceleração livre determinação da opacidade. Rio de Janeiro.

Andreoli I, Centurion JF (1999) Detailed survey of the faculty of agricultural sciences and veterinary Jaboticabal. In: Proceedings Brazilian Soil Science Congress (T025-3 CDROM):1-32

ANP - Agência nacional do petróleo, gás natural e biocombustíveis (2013). Resolution ANP $\mathrm{N}^{\circ} 65$ of 9 december, 2011.

BP Statistical Review of World Energy (2014). Available at: www.bp.com/statisticalreview.

Brasil (2013) Empresa de pesquisa energética ministério das minas e energia. Balanço energético nacional relatório final de 2013 referente ao ano base 2012.

Brown TR, Brown RC (2013) A review of cellulosic biofuel commercial-scale projects in the United States. Biofuel Bioprod Bior. V7: 35-45.

Chauhan BS, Kumar N, Cho HM, Lim HCA (2013) Study on the performance and emission of a diesel engine fueled with karanja biodiesel and its blends. Energy. 56: 1-7.

Demirbas A (2009) Progress and recent trends in biodiesel fuels. Energ Convers Manage. 50: 14-34.
Durães JA, Drummond AL, Pimentel TAPF, Murta MM, Bicalho FS, Moreira SGC, Sales MJA (2006) Absorption and photoluminescence of buriti oil/polystyrene and buriti oil/poly (methyl methacrylate) blends. Eur Polym J. 42: 3324-3332.

Graboski MS, Mccormick RL (1998) Combustion of fat and vegetable oil derived fuels in diesel engines. Colorado institute for fuels and high altitude engine research and department of chemical engineering and petroleum refining, Colorado school of mines, Golden, CO USA Prog Energy Combust Sci. 24: 125-164.

Kalam MA, Masjuki HH, Jayed HH, Liaquat AM (2011) Emission and performance characteristics of an indirect ignition diesel engine fuelled with waste cooking oil. Energy 36: 397- 402 .

Lima LP, Lopes A, Oliveira MCJ, Neves MCT, Koike GHA (2012) Comparative operational performance of agricultural tractor run on biodiesel from dende and brazilian palm. Eng Agric. 20 (3): 234-243.

Lima LP, Lopes A, Oliveira MCJ, Neves MCT, Iamaguti PS (2013) Biodiesel in an agricultural tractor: operational behavior as a function of the type and proportions blended in diesel fuel. Eng Agric. Vicosa/MG, V21 N5: 447-455.

Lopes A (2006) Biodiesel em trator agrícola: desempenho e opacidade. Thesis ( $\mathrm{PhD}$ in Agronomy) - Faculdade de Ciências Agrárias e Veterinárias de Jaboticabal, Universidade Estadual Paulista, Jaboticabal/SP. 158 pages.

Luz Jr GE, Lima SH, Melo ACR, Araujo AS, Fernandes Jr VJ (2010) Direct syn the sis and characterization of LaSBA-15 mesoporous molecular sieves. J Mater Sci. 45: 1117-1122.

Mazziero JVG, Correa IM, Trielli MA, Bernardi JA, D'Agostinho MF (2006) Evaluating the pollutant emissions from a diesel engine using sunflower biodiesel as fuel. Eng Agric.V14 N4: 287-292.

Neves MCT, et al (2013) Performance of an agricultural tractor in function of biodiesel type (soybean $\mathrm{x}$ murumuru) in soil preparation. Eng Agric. V21 N4: 351-360.

Mccurdy AT, Higham AJ, Morgan MR, Quinn JC, Seefeldt LC (2014) Two-step process for production of biodiesel blends from oleaginous yeast and microalgae. Fuel. 137: 269-276.

Ramírez AI, Aggarwal SK, Som S, Rutter TPE, Longman DE (2014) Effects of blending a heavy alcohol $\left(\mathrm{C}_{20} \mathrm{H}_{40} \mathrm{O}\right.$ with diesel in a heavy-duty compression-ignition engine). Fuel. 136: 89-102.

SAE- Society of Automotive Engineers (1996) J1667 Recommended practice snap acceleration smoke test procedure for heavy-duty powered vehicles.

Silitonga AS, Masjuki HH, Mahlia TM I, Ong HC, Chong WT (2013) Experimental study on performance and exhaust emissions of a diesel engine fuelled with Ceiba pentandra biodiesel blends. Energ Convers Manage. 76: 828-836.

Silva TA, Assunção RMN, Vieira AT, Oliveira MF, Batista ACF (2014) Methylic and ethylic biodiesels from pequi oil (Caryocar brasiliense camb.): Production and thermos gravimetric studies. Fuel. 136: 10-18.

Souza GR, (2005) Experimental evaluation of heat trasnfer in a flame tube furnace using ethyl ester of vegetable oil and diesel oil. Dissertation (masters in mechanical engineering) - Escola de Engenharia de São Carlos, 87 pages.

Tabile RA, Lopes A, Dabdoub M J, Camara FT, Furlani CEA, Silva RP (2009) Mamona biodiesel in interior and metropolitan diesel in agricultural tractor. Eng Agr. V29 N3: 412 - 423.

UNESP - Universidade Estadual Paulista "Julio De Mesquita Filho"- Campus De Jaboticabal (2013) Department of mathematical sciences: weather station - normal data.

Valente OS, Silva MJ, Pasa VMD, Belchior CRP, Sodré JR (2010) Fuel consumption and emissions from a diesel power generator fuelled with castor oil and soybean biodiesel. Fuel 89: 3637-3642.

Vasudevan PT, Briggs M (2008) Biodiesel production - current state of the art and challenges. J Ind Microbiol Biot. 35: 42130. 